Journal of Amish and Plain Anabaptist Studies, Volume 1, Issue 1 (April), 2013

\title{
Realignment and Division in the Amish Community of Allen County, Indiana: A Historical Narrative
}

\author{
Christopher Petrovich ${ }^{1}$ \\ 515 Old Church Road \\ Pearisburg, Virginia 24134
}

\begin{abstract}
The Amish have long faced disagreement over matters of internal policy and adoption of external ideas like evangelical emphases. In Allen County, Indiana, several branches of Anabaptists have developed from the original Swiss Amish settlers because of such differences. This article first reviews the history of new movements among the Amish. It then provides a historical narrative of the events that led to a New Order Amish schism in 2004, emphasizing how fundamental differences between the New Order's evangelical theology and the Old Order Amish worldview played out on several symbolic fronts, including young adult behavior, home Bible studies, lines of fellowship, understanding of the Ordnung, church membership, re-baptism, excommunication and shunning, and language use in services. Even after the division, neither the New Orders nor the Old Orders were completely unified. The New Order church eventually dispersed with a Charity Church replacing it. Within the Old Order, a toned-down evangelical pulse continues, giving rise to some reforms in youth behavior and stress on internal religious experience. This case of Allen County Amish points to the importance of doctrinal, theological, and practical differences in shaping collective behaviors that leads to new movements among the Amish.
\end{abstract}

Keywords: Swiss Amish, New Order Amish, Charity Churches, youth, shunning, rebaptism, evangelical theology, Ordnung, division,

\section{Erratum (updated November 2013)}

'Abstract: The following line change has been made: "It then provides a historical narrative of the events that led to a New Order Amish schism in 2004..."

'Pg. 169, paragraph four, line one: “(1)” has been eliminated.

'Figure 1, box 11: “...the Charity Church and...” has been removed.

${ }^{\circ} \mathrm{Pg}$. 174, paragraph two: The following has been added: “... several bishops organized meetings with fellow church leaders and parents of the youth in an attempt to promote stronger moral behavior before and especially after baptism. 


\section{Realignment and Division in the Amish Community of Allen County, Indiana: A Historical Narrative -- Petrovich}

\section{Introduction}

The Amish have encountered a bewildering array of religious persuasions and cultural sentiments since their immigration to the New World (Noll 1992). Protestant traditions, freed from the confines of European religious establishments, began competing for adherents in the open market of more egalitarian America, where to a considerable extent governmental and religious authority was exchanged for the sovereignty of individual conscience, and traditional forms of religious ritual yielded to more privatized forms of Christian piety (Hatch 1989). Although the Amish have rarely engaged in religious proselytization, they have not been exempt from internal disputes regarding the precise nature of Wahre Christentum (true Christianity) or the appropriation of more democratized and experiential forms of Christianity (Nolt 2003). The impact of external pressures has partially been blunted by the more insular nature of Amish existence (Hostetler and Huntington 2001), but internal disagreements (primarily concerns peculiar to Anabaptism) are a regular feature of the Amish community in Allen County, Indiana, as it has been in many other Amish settlements, resulting in occasional divisions and realignments.

The purpose of this article is to describe the main contours of the Allen County Amish story in terms of division and realignment. I provide an historical narrative of events leading up to and resulting from the disagreements which arose in 2004. In concluding this article, I present an overview of the outcome seven years later.

In August of 2004, I withdrew from the History of Christianity program at the Wheaton College Graduate School and relocated to northeast Indiana. Although I frequented Old Order services, as well as an occasional mid-week meeting held in a neighboring conservative Anabaptist congregation, I regularly attended the emerging New Order church and eventually became a member. Before the new movement organized its own youth activities, I attended an Old Order group dubbed 'the Supper Bunch.' I also became acquainted with Allen County Old Orders who welcomed me into their homes and invited me to weddings and funerals. In fact, two van loads of Old Orders traveled to the highlands of southwest Virginia to help remodel a house that I still call home. Therefore, I was an eyewitness of the events which transpired from August of 2004 until the fall of 2007, and remain in contact with families from each side of the division which arose in 2004. All other information is based upon historical research and personal interviews conducted with members from each of the Anabaptist groups in Allen County. 
Journal of Amish and Plain Anabaptist Studies, Volume 1, Issue 1 (April), 2013

\section{The Setting}

Allen County, established in 1824 out of Delaware and Randolph counties, was named for Colonel John Allen, an attorney and Kentucky state senator who was killed in the war of 1812. It is the largest county in the state of Indiana at 657 square miles, and as of the census of 2010, its population stood at 355,329, with a population density of 541 persons per square mile. The city of Fort Wayne was founded along three rivers - the Maumee, St. Joseph, and St. Mary's - and became the county seat in 1824. According to the 2010 census, the city's population was 253,691 (US Census Bureau www.census.gov).

The city limits of Fort Wayne hug the western edge of the Amish community in Allen County, which is also known as the Grabill/New Haven settlement (Luthy, 2009). The longest distance of any Amish family to the city limits is about seventeen miles. Today it numbers approximately 800 households, about 3,500 adults and children, in 19 church districts. Of over 460 Amish communities in North America, it is the $9^{\text {th }}$ largest by population size and the $10^{\text {th }}$ largest in terms of the number of church districts (Donnermeyer, Anderson, and Cooksey, 2012).

The Allen County history shows many divisions and realignments, which is typical for a number of settlements, including almost all of the older and larger Amish communities (Hostetler 1993; Waldrep 2008). The specific details of these attempts to sort out what it means to be Amish can be hard to follow. I describe this dynamic with the aid of Figure 1, which shows in graphic form both historical and contemporary realignments. The numbers in the narrative correspond to various groups displayed in Figure 1.

\section{The Amish in Allen County: 1853 - 1990}

The Amish community in Allen County was established in 1853-54 by a wave of immigrants from the Montbéliard region (Thompson 1994) who had lingered in Stark County, Ohio, before settling in northeastern Indiana (Beachy 2011). Peter Graber, first ordained to the ministry while in Stark County, was ordained bishop in Allen County on May 6, 1854 (Stoll 1997). It was not long until disagreements arose over doctrine, disciplinary standards, and forms of piety (Schwartz 2009). The Great Schism, which divided the North American Amish early in the second half of the nineteenth century, gave rise to a three-way division in Allen County (Yoder 1991). First, in 1861, from Peter Graber's church (1) a group separated and formed the Leo Amish-Mennonite Church (2) (Wenger 1961). 
Realignment and Division in the Amish Community of Allen County, Indiana: A Historical Narrative -- Petrovich

\section{Figure 1: Division and Realignment of the Amish in Allen County, IN}

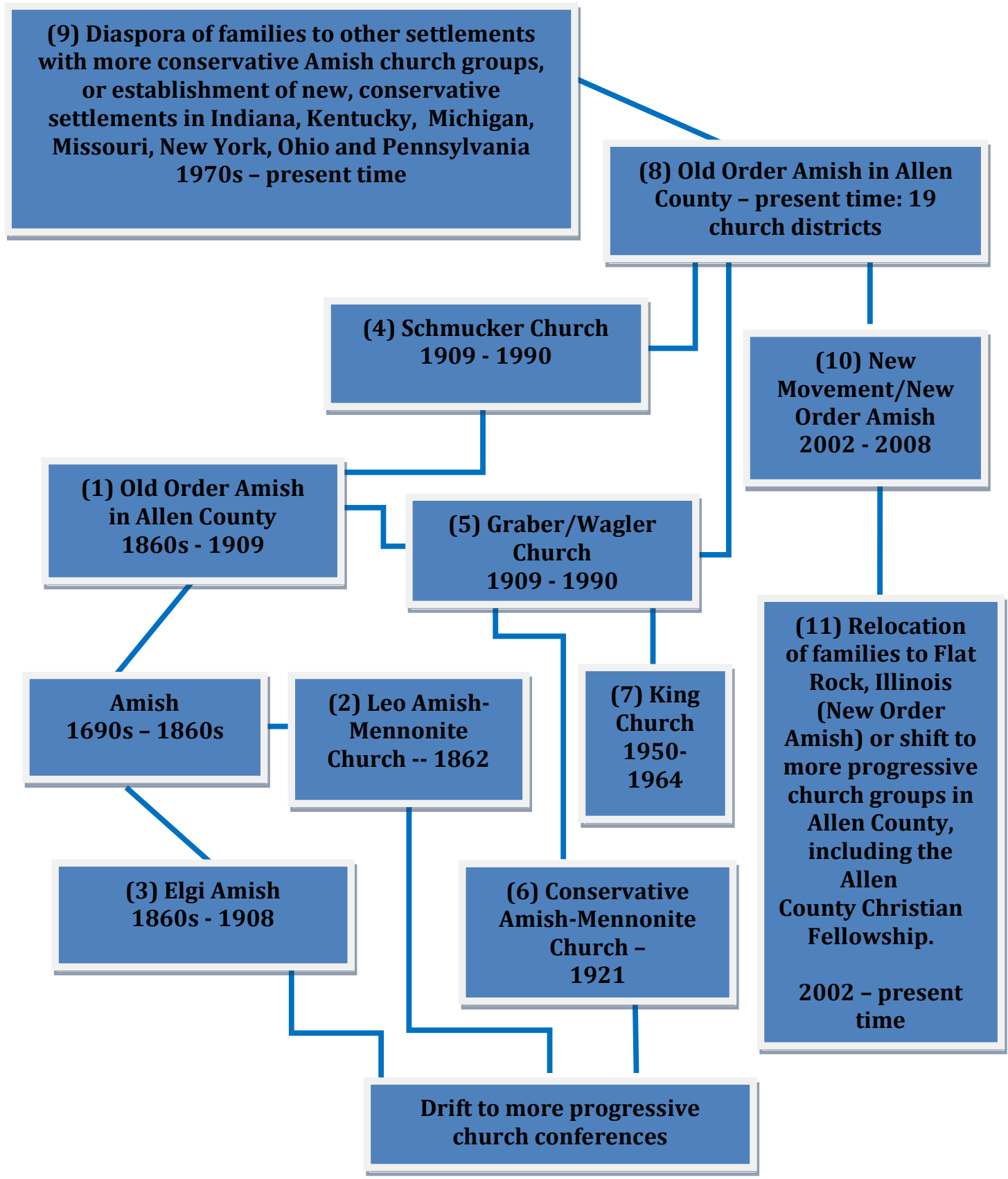


Journal of Amish and Plain Anabaptist Studies, Volume 1, Issue 1 (April), 2013

Second, six Allen County Amish ministers attended the Allgemeine Diener Versammlung (church-wide ministers' meeting) either in 1864 or 1865 . In spite of their efforts to bring unity to the Allen County congregation, Joseph and Andrew Gerig withdrew from Peter Graber's church and established a congregation which affiliated with the Egly Amish (3) in $1866 .^{2}$ Third, of the remaining four ministers, brothers Jacob and John Graber moved to Daviess County (IN) while John Klopfenstein and Michael Miller remained with Peter Graber's congregation. Although the Leo Amish-Mennonite Church united with the Mennonites by 1917, the Egly Amish eventually became the most progressive of the three groups (Ringenberg 1976).

The Amish community of Allen County consisted of one church district at the time of the division and remained so until the early part of the twentieth century. In 1909, the church divided over the use of the grain binder and steam engine. The conservative faction was dubbed the Schmucker church (4) and the more progressive faction the Graber church (5). In 1931, the single Schmucker district experienced turbulence. In response, the ministry allowed nine material items (Schwartz 2009). At about the same time twelve families left the Graber church (subsequently referred to as the Wagler church) and joined the Conservative Amish-Mennonite church (6) which had been established in $1921 .^{3}$

By the 1950s, the Amish had eight church districts, three 'Wagler' districts and five 'Schmucker' districts. In 1950, a second group left the Wagler church. This group, called the King church (7), had resisted Wagler's attempts to enforce Streng Meidung (strict shunning), divest the church of steel wheeled tractors and lazybacks on the buggies, and unite with the more conservative Schmucker church (Schwartz 2009). ${ }^{4}$ The application of Bann (excommunication) and Meidung (shunning) were especially controversial topics among the North American Amish during the 1950s, resulting in the Joe L. Shetler division in Adams County, Indiana (Nolt and Meyers 2007) and the "Andy Weaver" or Dan separation in Holmes County, Ohio (Hurst and McConnell 2010). In fact, leaders of the Andy Weaver faction helped ordain a bishop in the (Grabill) South district in 1956 (Schwartz 2009).

Two ministers from each side of the 1909 Schmucker/Graber rift signed the 1955 Diener Beschluß (ministerial decision), signifying their unity with other church leaders and congregations which upheld the Streng Meidung position (Byler 2008). In 1990, the separation between the Schmucker and Graber/Wagler churches was healed and the members of the remaining Graber West district were distributed among the ten Schmucker districts in accordance with geographical lines. Today, there are 19 Amish church districts (8), all of whom have resisted car ownership. The Leo Amish-Mennonite 


\section{Realignment and Division in the Amish Community of Allen County, Indiana: A Historical Narrative -- Petrovich}

Church, the Egly Amish, the Conservative Amish Mennonite and the King Amish continued their drift toward more progressive versions of Anabaptism and less plain lifestyles. Although they add to the Anabaptist diversity of Allen County, their specific histories are not directly germane to the remainder of this historical narrative.

\section{The Amish in Allen County: 1990 - 2000}

The Old Order Amish in Allen County are referred to as Swiss Amish and are readily identified by two cultural customs - their exclusive use of unenclosed buggies for transportation and hooks-and-eyes on men's shirts instead of buttons (Nolt 2008). Throughout most of its history the Allen County settlement has been noted for its particularly conservative way of life and has been aligned with more tradition-minded Old Order congregations, namely those maintaining the practice of strict shunning (Nolt and Meyers 2007). However, in the last quarter of the twentieth century, rising land prices, a penchant for operating highly successful mobile work crews (Kraybill and Nolt 2004), and in general a modernizing lifestyle was increasingly at odds with more conservative Amish and their views of consumption (Kraybill 1994). This prompted dozens of conservative families from the Allen County settlement to relocate over the past several decades (9), including at least seven bishops, fourteen ministers, and six deacons (Schwartz 2009). These families relocated to, or established, more conservative Old Order Amish communities in Steuben County - beginning in the 1970s before moving on to DeGraff, Ohio in the early 1990s; Norfolk, New York (1974); Quincy (1977) and Reading, Michigan (1979) (Huntington 2001); Linesville (1985) and Clarion, Pennsylvania (2000); Greentop, Missouri (2003); Fleminsgburg, Kentucky (2005); and DeKalb County, Indiana (2007). Their main objective was to preserve a more traditional and separate way of life typified by home-based occupations such as farming and smallscale sawmilling. This movement is consistent with what Donnermeyer and Cooksey (2010) have observed in other Amish communities:

This practice [a continuous search for new land] has served the Amish well, both in their early history on the North American continent, and especially in more recent times, as it has helped them find appropriate places to settle in the midst of an increasingly urbanized society, digitized culture and globalized economy. Within these rural oases, the Amish can make a living, run their households, raise their children and share in communal activities in ways consistent with core religious values, social organization and cultural patterns (181-82).

Thomas J. Meyers (1994) has observed that in the large Elkhart-LaGrange County settlement a noteworthy correlation exists between the rate of retention of Amish youth 
Journal of Amish and Plain Anabaptist Studies, Volume 1, Issue 1 (April), 2013

and the conservatism of the congregational Ordnung, with $37 \%$ defecting in the most liberal area (Shipshewana) while only $16 \%$ defect in the most conservative section of the settlement, around the village of LaGrange. Additionally, those that were raised in a rural setting were more likely to remain Amish (86\%) than those raised in close proximity to a town (80\%) (Meyers 1994). The contiguity of the Ft. Wayne metropolitan area (Meyers and Nolt 2005) with the western edge of the Allen County Amish settlement has occasioned high land prices and real estate taxes as well as more restrictive zoning regulations. These factors are prohibitive to the financial success of small-scale, family oriented home (and particularly farm) and home-based enterprises (Nolt and Meyers 2007). The closeness of Ft. Wayne also proffers a multitude of temptations for worldly behavior and had, at least in the eyes of many Amish, contributed to increasing disorder among the youth.

A majority of the families that relocated during the final quarter of the twentieth century shared a concern about the conduct of the Allen County youth (Längin 1994). Relocating in an attempt to improve the conduct of the youth is a technique which has been employed among the non-Swiss Amish as well, such as the movement out of Holmes County, Ohio, by some Amish to the Ashland area in the 1950s and then from Ashland to Stanwood, Michigan in 1982. The Glen/Fultonville, New York, settlement, which also originated out of Ashland, began in the spring of 2005 and has "reasserted strict behavioral guidelines governing the actions of the young folk" (Johnson-Weiner 2010, 109).

As a result of the steady exodus of conservative-minded church members, the remainder of the Allen County settlement was nudged a little bit closer to mainstream Amish thought and practice, typified by a higher standard of living and less distinctively Amish garb, including closely cropped beards for men, more transparent, shorter cut, and brightly-colored dresses among the women, and tennis shoes for all. In at least one instance, the Allen County community received a man into their church who was excommunicated by another Amish church without the Bann being lifted by the original congregation. When the Old Order churches in Allen County accepted the use of generators, self-propelled power equipment (such as forklifts and Bobcats), and mobile phones, more conservative Amish from other settlements severed fellowship ties with Allen County. Yet, in spite of their progressive leanings, the Old Order leadership resisted a new and even more progressive movement arising in its midst. 


\section{Realignment and Division in the Amish Community of Allen County, Indiana: A Historical Narrative -- Petrovich}

\section{The New Movement}

Several families began gathering for mid-week meetings in the spring of 2002. Each meeting was opened and closed with audible prayer, an uncommon practice in Old Order homes. These meetings utilized introductory study guides on the history of the early church and sixteenth-century Anabaptism which were written by an Amish-Mennonite convert. After completing the study guides, the meetings began to focus on the study of holy writ. Before long these meetings were labeled Bible studies, frowned upon or banned by many Amish groups, and came under the scrutiny of the church leaders from many of the Old Order church districts or groups in Allen County. Formal Bible study groups are not tolerated by most Old Order congregations because they typically operate outside traditional, established church structures. Although several Old Order congregations in Michigan (and elsewhere) have adopted ministry-led youth Bible study, most Old Orders reject this practice as well, deeming it questionable (i.e. not worth the risk), unnecessary, or a threat to Old Order conceptions of church structure and piety. It is also seen as questionable by some because its historical antecedents are found in progressive Amish-Mennonite and Evangelical Protestant movements, and looked upon with skepticism by those who believe it favors personal interpretation over communal consensus and inward piety as the external embodiment of New Testament precepts (Hood, Hill, and Williamson 2005).

Bible study attendees objected to the conduct of the Old Order youth of Allen County. In response to this concern, voiced throughout the community and not merely by those attending Bible study, several bishops organized meetings with fellow church leaders and parents of the youth in an attempt to promote stronger moral behavior before and especially after baptism. These meetings emphasized the role of parents in shaping the lives of their youth but did not incorporate the doctrine of the new birth into the reform program. However, many Bible study participants believed that these leaders typically failed to highlight the importance of the new birth, hence, the disorderly conduct of the youth could be traced to a lack of spiritual vitality. Since the lack of spiritual vitality was a result of not being born again, they were dissatisfied with the establishment's program of reform. After a few attempts to reconcile their differences, some of the more conservative bishops took action against those who participated in mid-week meetings, excommunicating them from the Old Order church. Since most of these families had become increasingly dissatisfied with various aspects of the doctrine and polity of the Old Order church, the leadership's firm response resulted in antagonism between the emerging sides. 
Journal of Amish and Plain Anabaptist Studies, Volume 1, Issue 1 (April), 2013

Within many evangelical Protestant theological traditions, the new birth entails admission into the kingdom of God, confers the forgiveness of sins, and bestows a new, Christ-like nature on the believer via the indwelling presence of the Holy Spirit (Erickson 1998). The Bible study group made efforts to promote this evangelical rendition of the new birth but most Old Order ministers objected to talk of being indwelt by the Holy Spirit, being forgiven of all their sins, or knowing that they have become members of the kingdom of God, particularly as a result of having a religious experience. Instead, most Old Order ministers emphasized the importance of being faithful to their baptismal vow to the church and treated "justification and reconciliation with God, not as an end in itself, but merely as a means to an ascetically holy life" (Weber 2002, p. 153). This emphasis, which is characteristic of Pietism, assumes an Amish flavor in that "Amish asceticism" rejects trendy clothing styles and certain modern conveniences. For most Old Order ministers, proclaiming to be certain of one's eternal destiny was deemed spiritual pride. Rather than strongly affirming the importance of the new birth while disapproving of the doctrine of assurance, the Old Order typically avoided affirming either. Exceptions to this rule were found scattered throughout the Allen County community, with as many as eight ministers embracing a more evangelical emphasis on the new birth. Two of these ministers were already bishops and two more would be ordained to the bishop's office over the next five years. However, only two of these eight joined the new movement.

Several members of the Old Order church began to proclaim that they had experienced a dramatic conversion experience and as a result acquired victory over profane language, illicit drugs, etc., which they had not experienced during their old life in the Old Order church. Two like-minded families had previously left the Allen County settlement and joined a Charity church in Lancaster County, Pennsylvania. The Charity movement, which began in 1982, was an attempt to re-establish an original New Testament, Christ-centered church in Lancaster County. The Charity movement focused on the doctrine of Christian conversion, emphasized the importance of attaining assurance of one's salvation, rejected the construction or application of an Amish-style Ordnung, and became involved in evangelistic and missionary endeavors with a revivalist flavor. The assurance of salvation is the concept that God informs the believer that they are a child of God via inward or outward signs, such as the presence of a clear conscience or love for Christian brethren. The two families who relocated to Pennsylvania promoted their doctrines from afar, primarily through discussions with family members back in Allen County, several of whom joined the new movement. ${ }^{5}$

The initial stirrings which endowed the new movement with vigor in Allen County originated from various sources. An Old Order Amish bishop, who later left the Amish by communing with the Reformed churches in Europe, stoked the fires through revival- 


\section{Realignment and Division in the Amish Community of Allen County, Indiana: A Historical Narrative -- Petrovich}

style preaching and an appeal to genuine heart religion when visiting relatives in Allen County (Girod 2000). Reading Scripture at home in the English language contributed an influential role in the stirrings, especially when set within the context of their new interpretation of church history. Further influence came from literature distributed by the Charity churches, popular evangelical books on spirituality, such as World Challenge Pulpit Series newsletters, and a Southern Baptist counselor who preached at an Old Order gathering. Over the next two years more than a dozen families were excommunicated by Allen County Old Order churches for refusing to discontinue mid-week Bible study meetings, proclaiming to have experienced a dramatic conversion experience, or embracing an evangelical rendition of the doctrine of the new birth. The latter two charges were typically presented as having a disobedient or proud spirit or replaced by a charge of having failed to shun someone who had been excommunicated by an Old Order congregation. The more prominent Old Order ministers of Allen County argued that the new birth is a gradual process and therefore to assert that one is born again is presumptuous and an evidence of pride. Since this opinion was not universally embraced among the leaders of the Allen County community, disciplinary action for embracing an evangelical rendition of the new birth or the doctrine of assurance was limited to a few districts.

Bishop Daniel Schmucker of the Northeast II district was sympathetic with the new movement and suggested that he would be willing to receive them into his church group. However, this suggestion was not accepted by the other bishops. Schmucker had initiated mid-week congregational singings that utilized English songbooks a few years earlier. These congregational singings led to the establishment of community singings which were concluded with a sermon on a select religious topic. It was during these times, as well as during sermons in his home district, that Schmucker emphasized the necessity of being born again and importance of leading a holy life.

As time went on, dissatisfaction with the Old Order intensified because it appeared as though the leaders were willing to take a firm position against the new movement but not against the disorderly youth of Allen County. Near the end of 2003, Schmucker began

meeting with the families who had been excommunicated. In spite of various attempts, no reconciliation between these families and the Old Order seemed imminent. In light of this, as well as the Old Order leadership's hesitancy, and at times hostile refusal, to promote an evangelical rendition of the new birth, their unwillingness to excommunicate all church members who were caught using alcohol or illicit drugs while routinely excommunicating anyone who joined a more liberal but morally upright and non-resistant church, and a perceived lack of moral integrity and evangelical zeal, Bishop Schmucker 
Journal of Amish and Plain Anabaptist Studies, Volume 1, Issue 1 (April), 2013

organized a new church on August 28, 2004. At the first church service the Bann was lifted from several families, restoring their membership after having been excommunicated by the Old Order church. The Old Order leadership refused to recognize this action and proceeded to excommunicate Bishop Daniel Schmucker and his wife the following Sunday. Members of the Allen County Amish who sympathized with the concerns raised by the new movement were now forced to choose sides.

The action taken against Schmucker and the Bible study attendees raised questions concerning the proper use of excommunication and shunning. Who should be excommunicated, and under what circumstances? The new movement suggested that sins explicitly mentioned in Scripture as barring one from heaven - lying, adultery, murder, hatred, etc. - provide the only basis for excommunication. The Old Order countered this argument by pointing out that the New Testament warrants excommunication for offenses not specifically named in Scripture but which are of a similar type or degree. They cited Galatians 5:19-21 in support of their argument. Verse 21 identifies "envyings, murders, drunkenness, revellings, and such like" as behavior which characterizes an individual who "shall not inherit the kingdom of God." The Old Order argued that being unfaithful to the baptismal vow or driving an automobile fits into the category of "such like" behavior. The new movement disagreed. The issue also arose as to the proper application of shunning. Although it did not play an instrumental role in dividing the Allen County Amish community, a majority within Schmucker's new group rejected shunning as an instrument of social persuasion in favor of merely withholding communion from excommunicated members, a departure from Article 17 of the Dordrecht Confession of Faith, Jacob Amman's position during the Amish-Mennonite division of the 1690s (Roth 2002), and later disciplinary standards of the Amish, such as the Essingen Discipline of 1779 (McGrath 1989). ${ }^{6}$

The Old Order Amish promote what Robert Friedmann termed 'Existential Christianity.' Existential Christianity is the concept that true Christian piety is logically and necessarily linked with external expressions of inward piety (Friedmann 1998). The Old Order are inclined to focus on church structures which clearly delineate the borderline between the church and the world. This delineation, which is embodied in the written and unwritten standards of the community, is linked with a consistent application of excommunication and shunning for those who habitually transgress such boundaries. The new movement viewed such borders and the selective nature of these borders, such as allowing use of electricity from private generators but not off the public utility line or excommunicating members for owning a vehicle but not for bouts of anger, with skepticism. The new movement, rather than focusing on external regulations, was concerned about the proper means of enacting inward spiritual transformation and 


\section{Realignment and Division in the Amish Community of Allen County, Indiana: A Historical Narrative -- Petrovich}

defined external expressions of this inward piety in terms of abstinence from tobacco and alcohol, victory over fleshly temptations, etc. Rather than denying that inward transformation produced outward forms of transformation, the new movement challenged the notion that inward transformation should be defined in terms of obedience to the Ordnung of the Amish church.

Ordnung, the compilation of regulations which governs each local church group or district ensures the embodiment of Amish ideals and is indispensable to the maintenance of the Amish social order (Hood, Hill, and Williamson 2005) because it is the primary means by which they self-consciously manipulate their path of social development (Olshan 1994).

In the Ordnung the Amish find "a universe with meaning and moral structure, a creation with which humans could harmonize if they would only grasp its pattern and live by its moral design" (Schlabach 1988, p. 209). Congregations, and in certain cases communities, produce a written Ordnungsbrief (letter of regulations) which delineates the main contours of expected behavior. Twice a year, in preparation for communion services, the bishop not only reads the Ordnungsbrief to the congregation but also reminds them of specific regulations not clearly stated in the Ordnungsbrief but which have been agreed upon by the community (Johnson-Weiner 2010). These regulations touch on matters such as mode of transportation, dress style, and church polity (Cronk 1981).

Over the next several months approximately twenty families aligned themselves with the new movement, resulting in a second round of excommunications. ${ }^{7}$ After several months, Schmucker's group received assistance from the conservative side of the New Order Amish of Holmes County, Ohio (Kraybill 1994). In general, New Order church groups have been more tolerant of technological innovation than most Old Orders and have endeavored to emphasize Christian piety without neglecting fundamentals of Old Order existence including boundary maintenance and obedience to church leadership. However, more conservative New Orders have rejected the use of tractors in the field and electricity from the public utility line, practices which are common in most other New Order settlements as well as the Aden church which seceded from them in the 1970s, also known as the New New Order or New Order Christian Fellowship (Beachy 2011). ${ }^{8}$ New Order Amish leaders from Holmes County were interested in assisting Schmucker's congregation because they too had earlier divided from the Old Order in an attempt to promote and enforce high courtship standards, emphasize Christian piety, ban the use of tobacco and alcoholic beverages, and improve Scriptural literacy among the laity (Stevick 2007). 
Journal of Amish and Plain Anabaptist Studies, Volume 1, Issue 1 (April), 2013

Several New Order bishops met with the new group and organized a church in Allen County in 2005. Oversight came from New Order bishops from Flat Rock, Illinois and Belle Center, Ohio. This new group also received regular visits from families and leaders in Holmes County, Ohio, and Rosebush, Michigan. Several months later communion was held for the first time at the residence of a family in the new Schmucker group. This transition, however, was not without tension. Several members of the new movement questioned the importance of establishing a clear membership roster, assembling a written Ordnung, refusing to extend the holy kiss to members of other conservative Anabaptist congregations, and rejecting an Old Order minister and his wife who had applied for membership, with the result that several families declined to have their names included in the membership roster. These families later formed the nucleus of what would become Allen County Christian Fellowship (11), a congregation which aligned with the Charity churches.

The Amish have forged a distinct identity and strengthened the bonds of communal solidarity in an effort to ensure their survival for future generations. They take very limited notice of human empires and economic factors, especially on a global scale, except where such factors impinge upon the economic dynamics of their local community, which Hostetler and Redekop (1977) refer to as "self-energizing." Rather than determining how they can take part in a global Christian community, they strive to build an ideal local church. This is their contribution to the world in the name of Jesus. This frees them from the difficult question of how and when unity can be forged with denominations of varying opinions and convictions. The Beachy Amish-Mennonites share certain aspects of the Amish approach. Members of this fellowship sometimes refer to themselves as the "in-betweeners," that is, between buggy driving Amish groups (including the New Order Amish) and almost all Mennonite affiliations. They are committed to recognizing other brethren as true believers even if they do not come from precisely the same denomination. This includes extending the holy kiss and sharing the pulpit with those of other nonresistant churches, and participating in Faith Builders, a post-secondary educational institute operated by conservative Anabaptist leaders primarily to train teachers. However, the Beachy churches, in common with the Amish, hold communion on a local basis, do not form close ties with congregations that reject any doctrine or practice they consider essential to Anabaptism, and require a clear membership roster and obedience to their written church standard.

The Charity churches, in an attempt to clear away what they call denominationalism and legalism, have rejected written church standards, recognize others as Christian brethren and sisters primarily according to the credibility of a verbal testimony rather than looking for the presence of traditional Anabaptist distinctives, and have demoted 


\section{Realignment and Division in the Amish Community of Allen County, Indiana: A Historical Narrative -- Petrovich}

church structures in favor of an emphasis on being led by the Holy Spirit. The new movement in Allen County was struggling to come to grips with these various issues, as evidenced by the hesitancy of some to embrace the concept of brotherhood as practiced by the New Order Amish.

Bishop Daniel Schmucker's congregation experienced significant change over the next year. The congregation grew rapidly, with more than forty families attending services by the end of the year. They continued to own mobile phones, maintaining the lifestyle of the progressive Allen County settlement. However, several noteworthy changes were introduced. First, the Allen County Amish had, more than nearly any other Amish settlement, lost a firm command of the German language. The Alsatian dialect, referred to as Swiss by Allen County residents (Thompson 1994), borrowed so many words from the English language that Schmucker's group considered their dialect hopelessly diluted. Furthermore, the high German (hoch Deutsch) of Luther's Bible was nearly incomprehensible to everyone except for Schmucker himself. A majority within the New Order movement ascribed the deteriorating morals of the youth to the barriers erected by the use of the German language in church services. As a result, the English language was quickly adopted for use in Allen County New Order church services. Second, the Ausbund song book was replaced by a Beachy Amish-Mennonite hymnal containing faster, evangelical songs. It had long been the practice of the Old Order churches, due to the length of time required to sing the slow tunes, to sing only select portions of each chosen song. The switch to the Christian Hymnary and its faster-paced tunes enabled the congregation to sing each song the entire way through and to meditate on the complete message of the song. It also allowed them to incorporate more pietistic and revivalistic emphases into church hymnody in contrast to the slow rendition of imitatio Christi (imitation of Christ) of the Ausbund hymns, penned by sixteenth-century Anabaptist martyrs while detained by hostile authorities. As a result, an emphasis on the patient endurance of the 'bitter Christ' gave way to the more lively tunes of inspirational Protestantism, signifying a shift away from early modern European marginality and separation from the world (Reschly 2000). Third, the women adopted the New Order dress pattern which included the regular use of the Halsduch (cape) and Shatz (apron) with gathers instead of pleats. The women also began making their head coverings out of opaque material. ${ }^{9}$

With time electricity from the public utility line and tractors for field work were quietly accepted, a notable departure from the Old Order habit of strictly limiting the appropriation of technology around the home (Kraybill and Nolt 2004), and without vote on or formal discussion of the issues involved. However, deeper issues were brewing 
within the church. All but five of the married men believed that they had not had a valid baptism because they had not been born again before they were baptized. Furthermore, nearly all of these also suggested that they had not understood the Dordrecht Articles of Faith or the doctrine of the new birth at the time they were baptized. As a result, they concluded that their baptism was not valid in the sight of God and must be readministered. Bishop Schmucker was not of this persuasion but after resisting their demands for more than a year he finally consented to rebaptizing those who did not believe they had a true baptism, but with three stipulations: 1) all applicants must be instructed in the Dordrecht Articles of Faith and confess that they have now understood these articles properly, 2) each applicant must receive an enige Rote (agreeable vote) from the brotherhood to take this step, and 3 ) the mode of baptism will be pouring. The members who had been pushing for the introduction of rebaptism were dissatisfied with Schmucker's proposal and asked a minister from a Charity church in Pennsylvania to rebaptize them. The Charity churches were willing to countenance this course of action because they believed that baptisms performed apart from true faith and repentance are no better than infant baptisms. Whereas the New Order Amish advocate public confession as the means of rectifying an unsatisfactory baptism, the Charity churches deem such baptisms invalid and therefore require them to be properly re-administered. Some considered Schmucker unqualified to perform baptisms because they did not believe he had a valid baptism himself.

Over the next several weeks, nearly two-thirds of the church was immersed in a pond behind a cabinet shop in Grabill, thereby severing their ties and leaving the New Order church with less than twenty families. In early 2006, Marvin Graber, apparently with the approval of Schmucker, composed a church standard which reflected the practice and consensus of the remaining group that also included several points aimed at assuaging the concerns of the conservative New Order churches (Graber 2006). Some within the congregation resisted what they saw as the imposition of two men's opinions on the entire congregation while others were no longer certain they wanted to submit to New Order church structures. Although the written standard was approved by a majority of church members, Schmucker did not enforce its regulations. In September of 2006, the New Order Amish who had extended bishop assistance and communal fellowship sent a letter to Bishop Schmucker, notifying him of their decision to discontinue fellowship. The reasons cited included adopting the practice of adult rebaptism, approving several significant innovations to their Ordnung, and failing to blend in with other New Order congregations.

The New Order deny the necessity of adult rebaptism if an applicant was instructed by a church that adhered to the Eighteen Articles of Faith of the Dordrecht Confession 


\section{Realignment and Division in the Amish Community of Allen County, Indiana: A Historical Narrative -- Petrovich}

and was capable of understanding the doctrines they had been taught (New Order Amish churches of Holmes...1983). Since baptism is considered a symbolic rite which marks one's entrance into the visible community of faith, the New Order Amish were afraid that approving of rebaptism would upset the accepted social order of their communities (Spierling 2005), even communities formed around adult baptism. The New Order also feared that Schmucker's congregation was following the path blazed by the Aden church, the group that had separated from them in the 1970s in protest to a new emphasis many church leaders were placing on the importance of brotherhood. New Order leaders had begun backing away from what they determined was unnecessary emotionalism and began emphasizing a proper balance between faith and works in response to a growing realization that approximately half of their youth were leaving the Amish. The Aden church, instead, placed a strong emphasis on an individual's personal relationship with God and questioned the church's role in ensuring compliance with the Ordnung (Hurst and McConnell 2010). It appeared that Schmucker was doing the same. He was not only approving of changes in the Ordnung but also neglecting to enforce the rules that they had agreed on. Schmucker's congregation also contributed to this impasse by approving of informal ties with other denominations. Although the conservative New Order, which had eighteen districts in the Holmes County area plus nine scattered in five other states, severed fellowship with the Allen County New Order movement, Schmucker continued to fellowship with other branches of the New Order tree. However, his constituency was quickly dwindling.

Within months of the division between the Charity and New Order churches, several families from Allen County decided to relocate to the conservative New Order community located in Flat Rock, Illinois. From the fall of 2007 until the fall of 2008 nearly the entire remaining New Order congregation was rebaptized, including Bishop Schmucker himself. After financial difficulties and questions of honesty and integrity cropped up, the remaining members lost confidence in Schmucker's leadership and the congregation dispersed. All of the departing families united with the Allen County Christian Fellowship (Charity) congregation while Bishop Schmucker and his son, ordained to the ministry in the Allen County New Order church, joined a local conservative non-conference Mennonite congregation. Fifty-eight Allen County Old Order families from twelve different districts were now dispersed among four different Anabaptist affiliations in Indiana, Illinois, Ohio, and Kentucky.

\section{Discussion and Interpretation}

The primary points of contention among the Amish of Allen County were similar to those raised during the time of the Great Schism - doctrine, disciplinary standards, and 
Journal of Amish and Plain Anabaptist Studies, Volume 1, Issue 1 (April), 2013

forms of piety. The new movement advocated an evangelical rendition of the new birth as well as the doctrine of the assurance of salvation, argued that only those who have experienced inner spiritual enlightenment should be included within the boundaries of the church, employed new ecclesiastical programs such as Sunday School and Bible study groups, defined holiness primarily in terms of inner piety and moral integrity rather than obedience to the Amish Ordnung, and tended to view the Old Order procedures of Bann (excommunication) and Meidung (shunning) as little more than tools of social coercion.

The Old Order Amish spurn higher education, resist most church-like organizations, particularly theological seminaries, and tend to deem scholarly pursuits irrelevant to the Christian walk, if not detrimental (Oyer 1993). The Amish "have talked little about matters that the Dordrecht Confession does not detail, such as speculative eschatology [doctrine of the end times] or the exact nature of biblical authority." (Nolt 2008, p. 388) Their approach to life is more fittingly captured in Kraybill, Nolt, and Weaver-Zercher's recent title The Amish Way (Kraybill, Nolt, and Weaver-Zercher 2010). It tends more toward "walk" than talk.

The assurance of salvation is the tenet that a Christian can, and most likely should, know that they have been born again and are in possession of eternal life, which entails the forgiveness of sin and peace with God. While the new movement did not profess to be eternally secure, they did maintain that a believer should know whether or not they are at peace with God at the present moment and would therefore inherit eternal bliss if they were to die immediately. The Old Order shied away from the 'saved' appellation, which they equated with being indwelt by the Holy Spirit, because they considered it presumptuous to assert that one was sure of his or her salvation (Kraybill 2001). Although the Old Order was not unanimously opposed to this doctrine, it was consistently criticized by ministers who were fearful that a new form of piety was sprouting in Allen County. The Swiss Amish have not only been plagued by dissension more often than most other Amish groups but have experienced numerous rifts specifically caused by disagreements over the assurance of salvation, such as those which have arisen in Synder County in Pennsylvania, and Clyde and Prattsburg in New York (Johnson-Weiner 2010). This piety, despite appearing new to most members of the Old Order, was actually quite old (Hindmarsh 2005) and had been adopted by both the Amish-Mennonites who seceded from Peter Graber's church in 1861 and the King church which broke away from the Wagler church in 1950.

The assurance of salvation acquired tremendous importance as the new movement formulated its ecclesiology (doctrine of the church) in light of its soteriology (doctrine of salvation). The new movement concluded that there was sufficient basis to think that a 


\section{Realignment and Division in the Amish Community of Allen County, Indiana: A Historical Narrative -- Petrovich}

candidate should be examined on his or her personal experience with God. The Amish had traditionally allotted a place for verbal expression of one's faith (Hostetler 1993), but the dominant emphasis in determining whether an applicant was worthy of baptism was placed on their conduct, both public and private (as far as the community was able to observe). The new movement de-emphasized the role outward conduct played, particularly vis-à-vis the congregational Ordnung, because they argued that anyone could put on an impressive religious front. Their attempt to ensure the establishment of a pure church resulted in a fondness for personal conversion narratives but failed to address the question of how the corporate assembly is expected to determine the accuracy of the presentation of an independent practitioner of inward spirituality without having direct, unmediated access to such experiences.

Disagreements relating to the doctrine of salvation brought additional differences over church organization and structure into the spotlight. The Old Order emphasize that "the believing community, rather than the individual, is the locus of God's salvific activity" (Peterson 2005, p. 105). The new movement disagreed with this emphasis, shifting the focus to some extent from the authority and control of the community to the individual's direct access to God, analogous to the way sleeping preacher Noah Troyer had "appealed to individual conscience as the direct voice of God" (Reschly 2000, p. 157 ) in the last quarter of the nineteenth century in eastern Iowa. The result was a subtle shift in authority from the hierarchy of the church community to individual conscience.

The New Order Amish, despite descending from the Old Order side of the Great Schism, offer different conclusions to these disputed doctrines. Although they are reluctant to speak about 'salvation by faith alone' (Waldrep 2008), because they emphasize the centrality of repentance in the plan of salvation (Kline and Beachy 1998), they regularly emphasize the importance of the new birth and teach the assurance of salvation (Hurst and McConnell 2010; Stevick 2007). The New Order emphasize Christian piety and employ disciplinary measures on those who transgress moral rectitude, but obedience to the written Ordnung is also expected (Waldrep 2008; Kline and Beachy 1998). However, since the universal church is more readily defined by high standards of morality and piety, denominational fences are not as tall (Petrovich 2007). The universal church, then, is defined more in terms of inward Christian piety than external religious symbol. Although church members are allowed to join conservative Anabaptist congregations that own and operate automobiles without being excommunicated, no "fellowship - symbolized by the exchange of the holy kiss and preaching - is permitted with 'car churches."' (Waldrep 2008, p. 412) The new movement ultimately approved of adult rebaptism, was hesitant toward the New Order 
Journal of Amish and Plain Anabaptist Studies, Volume 1, Issue 1 (April), 2013

emphasis on the disciplined brotherhood, and crafted informal ties with congregations outside the New Order circle. The outcome was the dissolution of Schmucker's New Order congregation and the rapid emergence of not only a new vision but also a new congregation - Allen County Christian Fellowship - which aligned itself with the Charity movement.

The new movement did not originate as an attempt to liberalize the lifestyle of the Amish church. The outcome of the movement was not planned from the beginning but instead occurred because "leaders seeking strategies to do away with offensive customs sometimes accept new religious methods and carefully planned change as positive values ... Innovation, even in the conservative service of resisting assimilation, is dangerous for Amish identity" (Reschly 2000, p. 159). The new movement challenged the accepted order of the Amish community in Allen County, particularly the degree of tolerance shown toward unruly youth, their penchant for employing the tools of excommunication and shunning when deemed necessary to defend the social order of the Old Order community but refusing to employ them in cases involving flagrant and habitual moral misconduct, their beliefs about the doctrines of the new birth and the assurance of salvation, and what the new movement perceived to be a lack of emphasis on inward Christian piety more generally. The new movement itself seemed to have diverged from traditional Anabaptist thought in significant ways while converging with several emphases of Protestant Evangelicalism (Weaver 1997), such as a preference for highly emotive and experiential conversion experiences (Oyer 2000), discerning the spiritual condition of baptismal applicants primarily in light of a verbal testimony, a distaste for church regulations, and an emphasis on a life of spiritual victory over an emphasis on cross-bearing and patient endurance (Chan 1998). Their penchant for sharp criticism was not entirely new. The Swiss Amish are well known for being firm and unyielding in their opinions and slow to compromise (Nolt and Meyers 2007). Their seventeenth century Swiss Anabaptist predecessors were known to maintain "a drumfire criticism of the Reformed" (Oyer 2000, p. 106).

The new movement represented a consortium of Old Orders who earnestly desired to reform their church in accordance with the pattern they saw in the New Testament, as interpreted through their new perspective of what it meant to be an Anabaptist and a Christian. The main issues which provoked internal dissension revolved around the practice of adult rebaptism, attitudes toward the Amish in general and the New Order in particular, whether or not to extend the holy kiss to members of other Anabaptist denominations, and the necessity of having a written Ordnung (No author 2006). Approximately two years after the New Order/Charity division the remaining New Order congregation dissolved. Those who emphasized traditional Anabaptist motifs such as 


\section{Realignment and Division in the Amish Community of Allen County, Indiana: A Historical Narrative -- Petrovich}

endurance and self-sacrifice, cherished their Amish heritage, and did not view the church structure and spirituality of the Charity churches as the logical consequence of a simple reading of the New Testament text ultimately relocated to other Amish settlements.

\section{Seven Years Later}

The Old Order Amish population stands at nearly 2,000 members in nineteen church districts while the Charity movement has approximately 160 members that meet in one church building. Allen County Christian Fellowship purchased the bulk food store when a family relocated to the New Order settlement in Flat Rock, Illinois. The Charity congregation remodeled the building and uses it as a meetinghouse. Most families have chosen to homeschool, in contrast to near universal attendance of Old Order children at local parochial schools run by the Old Order churches (Harroff 2004). Allen County Christian Fellowship has been active in local evangelism, providing social relief to the poor and homeless in Fort Wayne, and overseas missionary work. They have conducted revival meetings and due to crowded conditions are considering the prospect of establishing another congregation. Members have been immigrating north in order to acquire cheaper land, especially into DeKalb County, Indiana, where property taxes are also considerably lower. They have plans in the near future of establishing a congregation near the DeKalb County town of Auburn. The Allen County Charity church fellowships with a variety of like-minded congregations throughout North America, mainly independent groups where women wear a head covering, non-resistance is practiced, and church regulations are kept to a minimum. Although they are on friendly terms with other local conservative Anabaptist groups they do not share fellowship with any of them. They have a special relationship with Bishop Eugene Eicher and Fellowship Haven, the only remaining Beachy Amish-Mennonite church in Allen County, because of Eicher's longheld desire to see revival come to the Old Order Amish of Allen County.

In spite of the division, the Old Order population continues to grow, becoming more densely populated in the center of the community but also slowly expanding to the north and east, away from the Fort Wayne metropolitan area. The Old Order church is unlikely to win any converts but neither are they particularly interested in such endeavors since they have been plagued with internal matters which require their attention. Over the past fifteen years their lines of church fellowship have gradually shifted. The Allen County community had previously refused the hand of fellowship to the Amish located in Elkhart and LaGrange counties because of their failure to uphold the practice of Streng Meidung, opting rather to lift the Bann after a former member becomes a faithful member of another plain, nonresistant congregation (Nolt and Meyers 2007). As a result of the rapid modernization which has occurred over the past twenty years, most Streng Meidung 
Journal of Amish and Plain Anabaptist Studies, Volume 1, Issue 1 (April), 2013

communities have disfellowshipped Allen County, particularly for their acceptance of generators, Bobcats, and the mobile phone. As a result, nearly all Old Order church districts in Allen County now share communion with the Amish of Elkhart and LaGrange Counties. With the acceptance of the mobile phone and frequency of automobile ownership by members of the Allen County Amish, they are positioned near the fringe of Amish existence.

The Old Order church in Allen County, despite the appearance of being in unified opposition to evangelical emphases, exhibits considerable diversity. Approximately ten out of seventy ministers emphasize the importance of the new birth and holiness without exalting personal convictions to an authoritative level. Some who advocate an evangelical emphasis also approve of Streng Meidung, combining the doctrine of salvation by faith in Jesus Christ with the concept that one must remain in the church in which they were baptized. Some ministers spurn most forms of modern technology and resist any ideas which might seem remotely related to the emphases advocated by the new movement while a few approve of adopting both modern technology and evangelical emphases. Efforts are being made to establish another New Order congregation but in a different location, in an attempt to avert conflict. The primary reason that New Order interests remain alive in Allen County is that some families are convinced that Allen County Old Order institutions offer little hope for moral and spiritual reform. The misconduct of the Old Order youth has perhaps improved slightly with the advent of two new youth groups who do not engage in the more rowdy conduct of the others. The perception of widespread parental acceptance of rowdy conduct and stories of out-of-wedlock pregnancies and alcohol and drug use, continue to cause concern. As a result, it seems likely that division will continue to be a characteristic of the Allen County community.

\section{Conclusion}

The evangelical stirrings that visited Allen County in the first decade of the present century reshaped the doctrine and piety of a considerable minority within the Amish community of Allen County, Indiana. This minority endeavored to enact changes that they believed would invigorate the spiritual life and reform the moral character of their community. The leadership attempted to halt such endeavors by expelling those who zealously promoted evangelical doctrines or proclaimed to have experienced a dramatic conversion experience, turning these issues into irreconcilable differences. Dozens of families refused to recognize the action of the older bishops which then led to a second round of excommunications. The community was torn between these two factions because many earnestly desired to see moral reform, even if not in precisely the same terms as explicated by the new movement. Many made the decision to join the new 


\section{Realignment and Division in the Amish Community of Allen County, Indiana: A Historical Narrative -- Petrovich}

movement without being induced by expulsion from the Old Order because they viewed Schmucker's New Order congregation as providing greater hope for moral and spiritual reform than the setting in which they were reared. The new movement, however, struggled to blend in with the New Order Amish, unify around a new common Amish identity, and sacrifice some of their personal opinions for the sake of unity. As a result, they began to fragment. Appeals for the abolition of church regulations and the necessity of adult rebaptism won the day, dividing the new movement and ultimately resulting in the relocation of those who retained a vision of having an Amish church reformed and revitalized according to their evangelical ideals.

The Anabaptist landscape in Allen County witnessed the addition of a short-lived New Order Amish congregation whose membership peaked at around fifty-five families, the departure of nearly ten percent of the Old Order community in favor of the new movement, and the replacement of the New Order congregation by an influential and growing Charity congregation. The conservative Anabaptist community in Allen County continues to contribute to the fragmented and kaleidoscopic nature of American religion, revealing the almost infinite number of ways in which American religious communities reassess their shared convictions and habits, and readjust their posture toward other communities of varying religious persuasions. 
Journal of Amish and Plain Anabaptist Studies, Volume 1, Issue 1 (April), 2013

\section{Endnotes}

${ }^{1}$ Christopher G. Petrovich earned a B.S. in Social Sciences from Liberty University and was a graduate student in the History of Christianity program at Wheaton College Graduate School before relocating to Allen County, Indiana, in the summer of 2004 . He was a member of the Allen County New Order congregation before moving to Pearisburg, Virginia, in the fall of 2007. Christopher G. Petrovich resides at 515 Old Church Road, Pearisburg, VA 24134.

${ }^{2}$ The Egly Amish formed in the 1850s around an articulate and charismatic bishop from the Swiss Amish settlement in Adams County (Indiana), Henry Egly. Egly drew followers from several Amish-Mennonite communities to form the Defenseless Mennonite affiliation. Egly deemed a vivid new birth experience a prerequisite for adult baptism and promoted personal evangelism. The Grabill Missionary Church emerged from a split in the Defenseless Mennonites. The Defenseless Mennonites later became known as Evangelical Mennonites but dropped the Mennonite insignia and recently constructed a new church building on the outskirts of Grabill, opting instead to be called the Crossview Church.

${ }^{3}$ The Conservative Amish-Mennonite church eventually adopted the name Conservative Mennonite Conference. Today, there are two congregations in Allen County who can trace their roots back to this division: the independent Conservative Mennonites, an autonomous group near the small town of Cuba; and the Sonrise Chapel which remains affiliated with the Conservative Mennonite Conference.

${ }^{4}$ In December 1964, the King church purchased an old church house along Ridgeview Road and adopted the name Ridgeview Amish-Mennonite (Miller 2000). The King church later divided and gave birth to Fellowship Haven (Woodburn, IN) which also experienced unrest that resulted in the establishment of Hicksville Christian Fellowship (Hicksville, $\mathrm{OH}$ ), the latter two aligning with the Beachy Amish-Mennonite fellowship (Anderson 2011).

${ }^{5}$ The Charity church has also rejected the technological restrictions of the Amish groups and are less alarmed at the influence that social networking (i.e. Facebook, Twitter, etc.) poses to the survival of local Anabaptist communities (Hipps 2009). Particulars of lifestyle and dress have become secondary issues or not issues at all, particularly for congregations located abroad. They continue to adhere to a church/world dualism but have occasionally questioned the sharp separation between themselves and other Protestants (Schelbert 1985). Their perspective on the Anabaptist vision is now being 


\section{Realignment and Division in the Amish Community of Allen County, Indiana: A Historical Narrative -- Petrovich}

lifted out of the cultural setting in which it was nurtured and embedded in a distinctly foreign environment. It is, to be sure, a work in progress and its results cannot be fully assessed at this time. The Charity vision not only emphasizes the centrality of the new birth and the assurance of salvation but requires a verbal testimony as a test of membership in which the applicant is expected to recount a vivid new birth/conversion experience. Whereas some Old Order congregations have considered the baptism of Mennonites and Dunkards insufficient because they were not in complete unity and uniformity of standard and practice with either denomination (Yoder 1991), the Charity movement looks to the inward experience of personal conversion as the talisman of Christian identity and the sole prerequisite for baptism. Spontaneity, individual conscience, and verbal expressions of faith hold a more central place in the Charity vision. It is not uncommon for an individual to recount dramatic life experiences, for families to sing a song, or laymen to preach a sermon as part of a Sunday morning worship service. The Charity churches place a significant emphasis on being led by the Holy Spirit. Traditional Anabaptist groups, including the New Order Amish and Beachy Amish-Mennonites, affirm the importance of being led by the Holy Spirit but do not suggest that the Holy Spirit would lead the individual believer to act contrary to Scriptural precepts or the application of Biblical principles as agreed upon by a local brotherhood (Friedmann 1949). While the Charity churches do not suggest that believers should act contrary to the revealed will of God in Scripture, their emphasis on personal discernment, for better or for worse, signals that they have moved from early-modern to modern religion, marked by a heightened spiritual inwardness and a new confidence in individual action (Noll 2002).

${ }^{6}$ The Eighteen Articles of Faith were composed in 1632 in Dordrecht, Holland. These articles, adhered to by both Old Order Amish and Old Order Mennonites, outline the foundational doctrines of Protestant Christianity and Anabaptist tenets such as foot washing, separation from the world, and nonresistance to evil.

${ }^{7}$ A total of fifty-eight families were excommunicated by the Old Order for matters relating to this schism, as of the spring of 2012.

${ }^{8}$ There are numerous accounts of New Order origins and diversity within the New Orders. See Beachy (2011), Hurst and McConnell (2010) and Nolt (2003; 2008), among others.

${ }^{9}$ For an example of the New Order head covering style see Anderson (2010). 
Journal of Amish and Plain Anabaptist Studies, Volume 1, Issue 1 (April), 2013

\section{REFERENCES}

Anderson, Cory. 2010. The Ornament of a Spirit: Exploring the Reasons Covering Styles Change. Medina: Ridgeway Publishing.

Anderson, Cory. 2011. "Retracing the Blurred Boundaries of Twentieth-Century 'AmishMennonite' Identity.” Mennonite Quarterly Review 85(3):361-411.

Beachy, Leroy. 2011. Unser Leit: The Story of the Amish. Walnut Creek: Carlisle Printing.

Byler, John M. 2008. Alte Schreibens. Sugarcreek: Schlabach Printers.

Chan, Simon. 1998. Spiritual Theology: A Systematic Study of the Christian Life. Downers Grove: InterVarsity.

Cronk, Sandra. 1981. "Gelassenheit: The Rites of the Redemptive Process in Old Order Amish and Old Order Mennonite Communities." Mennonite Quarterly Review 55(1):1-10.

Donnermeyer, Joseph and Elizabeth C. Cooksey. 2010. "On the Recent Growth of New Amish Settlements” Mennonite Quarterly Review 84(2):181-206.

Erickson, Millard J. 1998. Christian Theology, $2^{\text {nd }}$ Ed. Grand Rapids: Baker.

Friedmann, Robert. 1949. Mennonite Piety Through the Centuries: Its Genius and Its Literature. Studies in Anabaptist and Mennonite History, Vol. 7. Scottdale: Herald.

Friedmann, Robert. 1998. The Theology of Anabaptism: An Interpretation. Eugene: Wipf and Stock.

Girod, Ben. 2000. Rekindling the Anabaptist Flame: What Does God Want From the Plain Churches of Today? Sugarcreek: Carlisle.

Graber, Marvin. 2006. "Us Brother of Allen County, IN, New Order Amish denomination, believe in a structural, written standard." Copy in the hand of Christopher G. Petrovich. 


\section{Realignment and Division in the Amish Community of Allen County, Indiana: A Historical Narrative -- Petrovich}

Harroff, Stephen Bowers. 2004. The Amish Schools of Indiana: Faith in Education. West Lafayette: Purdue University Press.

Hatch, Nathan O. 1989. The Democratization of American Christianity. New Haven: Yale University Press.

Hindmarsh, Bruce D. 2005. The Evangelical Conversion Narrative: Spiritual Autobiography in Early Modern England. New York: Oxford University Press.

Hipps, Shane. 2009. Flickering Pixels: How Technology Shapes Your Faith. Grand Rapids: Zondervan.

Hood Jr., Ralph W., Peter C. Hill, and W. Paul Williamson. 2005. The Psychology of Religious Fundamentalism. New York: The Guilford Press.

Hostetler, John A. 1993. Amish Society. Baltimore: Johns Hopkins University Press.

Hostetler, John A., and Gertrude Enders Huntington. 2001. Amish Children: Education in the Family, School, and Community. Mason: Cengage.

Hostetler, John A., and Redekop, Calvin W. 1977. "The Plain People: An Interpretation.” Mennonite Quarterly Review 51:266-277.

Huntington, Gertrude Enders. 2001. Amish in Michigan. East Lansing: Michigan State University Press.

Hurst, Charles E., and David L. McConnell. 2010. An Amish Paradox: Diversity and Change in the World's Largest Amish Community. Baltimore: Johns Hopkins University Press.

Johnson-Weiner, Karen M. 2010. New York Amish: Life in the Plain Communities of the Empire State. Ithaca: Cornell University Press.

Kline, Edward A., and Monroe L. Beachy. 1998. "History and Dynamics of the New Order Amish of Holmes County, Ohio." Old Order Notes 18:7-19.

Kraybill, Donald B. 1994. "War Against Progress: Coping with Social Change" in The Amish Struggle with Modernity. Edited by Donald B. Kraybill and Marc A. Olshan. Hanover: University Press of New England. 


\section{Journal of Amish and Plain Anabaptist Studies, Volume 1, Issue 1 (April), 2013}

Kraybill, Donald B. 2001. The Riddle of Amish Culture. Baltimore: Johns Hopkins University Press.

Kraybill, Donald B., and Carl Desportes Bowman. 2001. On the Backroad to Heaven: Old Order Hutterites, Mennonites, Amish, and Brethren. Baltimore: Johns Hopkins University Press.

Kraybill, Donald B., and Steven M. Nolt. 2004. Amish Enterprise: From Plows to Profits. Baltimore: Johns Hopkins University Press.

Kraybill, Donald B., Steven m. Nolt, and David Weaver-Zercher, 2010. The Amish Way: Patient Faith in a Perilous World. San Francisco: Jossey-Bass.

Längin, Bernd G. 1994. Plain and Amish: An Alternative to Modern Pessimism. Scottdale: Herald.

McGrath, William. 1989. Christian Discipline: How and Why the Anabaptists Made Church Standards. Minerva: Amish-Mennonite Publications.

Meyers, Thomas J. 1994. "The Old Order Amish: To Remain in the Faith or to Leave" Mennonite Quarterly Review 68(3):378-395.

Meyers, Thomas J., and Steven M. Nolt. 2005. An Amish Patchwork: Indiana's Old Orders in the Modern World. Bloomington: Indiana University Press.

Miller, Devon (ed.). 2000. Amish-Mennonite Directory 2000: United States and Canada. Millersburg: Abana Books.

"New Order Amish churches of Holmes, Wayne, and Tuscarawas County, 'Conclusions regarding the matter of re-adult baptism.' 24 January 1983. Photocopy in the hand of Christopher G. Petrovich.

Nichols, Stephen J. 2002. Martin Luther: A Guided Tour of His Life and Thought. Phillipsburg: P\&R Publishing.

Noll, Mark. 1992. A History of Christianity in the United States and Canada. Grand Rapids: Eerdmans.

Noll, Mark. 2002. America's God: From Jonathan Edwards to Abraham Lincoln. New York: Oxford University Press. 


\section{Realignment and Division in the Amish Community of Allen County, Indiana: A Historical Narrative -- Petrovich}

Nolt, Steven M. 2003. A History of the Amish. Intercourse: Good Books.

Nolt, Steven M. 2008. "Who are the Real Amish?: Rethinking Diversity and Identity Among a Separate People.” Mennonite Quarterly Review 82(3):377-94.

Nolt, Steven M. and Thomas J. Meyers. 2007. Plain Diversity: Amish Cultures \& Diversities. Baltimore: Johns Hopkins University Press.

Olshan, Marc A. 1994. "Modernity, the Folk Society, and the Old Order Amish" in The Amish Struggle with Modernity. Edited by Donald B. Kraybill and Marc A. Olshan. Hanover: University Press of New England.

Oyer, John S. 1993. “Is There An Amish Theology?” Pp. 278-302 in Les Amish: Origine Et Particularismes, 1693-199. Edited by Lydie Hege and Christoph Wiebe. De Sainte-Marie-aux-Mines: 1'Association Francaise d'Histoire AnabaptisteMennonite.

Oyer, John S. 2000. "They Harry the Good People Out of the Land”: Essays on the Persecution, Survival and Flourishing of Anabaptists and Mennonites. Goshen: Mennonite Historical Society.

Peterson, Anna. 2005. Seeds of the Kingdom: Utopian Communities in the Americas. New York: Oxford University Press.

Petrovich, Christopher G. 2007. "Evangelical and Amish: An Introduction to the New Order Amish." Paper Presented at the Christianity and American History Conference, Lynchburg, Virginia.

Reschly, Steven D. 2000. The Amish on the Iowa Prairie: 1840 to 1910. Baltimore: Johns Hopkins University Press.

Ringenberg, William C. 1976. "Development and Division in the Mennonite Community in Allen County, Indiana.” Mennonite Quarterly Review 50(2):114-131.

Roth, John D. (trans. and ed.). 2002. Letters of the Amish Division: A Sourcebook. Goshen: Mennonite Historical Society.

Schelbert, Leo. 1985. "Pietism Rejected: A Reinterpretation of Amish Origins" in America and the Germans: An Assessment of a Three-Hundred-Year History. Vol. 
Journal of Amish and Plain Anabaptist Studies, Volume 1, Issue 1 (April), 2013

1: Immigration, Language, Ethnicity. Edited by Frank Trommler and Joseph McVeigh. Philadelphia: University of Pennsylvania Press.

Schlabach, Theron F. 1988. Peace, Faith, Nation: Mennonites and Amish in NineteenthCentury America. Scottdale: Herald.

Schwartz, Victor L. 2009. Allen County Church Tree: 1854-2009. Sugarcreek: Carlisle.

Spierling, Karen E. 2005. Infant Baptism in Reformation Geneva: The Shaping of a Community, 1536-1564. Louisville: John Knox University Press.

Stevick, Richard A. 2007. Growing Up Amish: The Teenage Years. Baltimore: Johns Hopkins University Press.

Stoll, Joseph. 1997. The Amish in Daviess County, Indiana. LaGrange: Lambright.

Thompson, Chad. 1994. "The Languages of the Amish of Allen County, Indiana: Multilingualism and Convergence.” Anthropological Linguistics 36 (1): 69-91.

Waldrep, G.C. 2008. “The New Order Amish and Para-Amish Groups: Spiritual Renewal within Tradition.” Mennonite Quarterly Review 82(2):395-426.

Weaver, J. Denny. 1997. Keeping Salvation Ethical: Mennonite and Amish Atonement Theology in the Late Nineteenth Century. Studies in Anabaptist and Mennonite History, Vol. 35. Scottdale: Herald.

Weber, Max. 2002. The Protestant Ethic and the "Spirit" of Capitalism and Other Writings. Edited and Translated by Peter Baehr and Gordon C. Wells. New York: Penguin.

Wenger, John C. 1961. The Mennonites in Indiana and Michigan. Studies in Anabaptist and Mennonite History, Vol. 10. Scottdale: Herald.

Yoder, Paton. 1991. Tradition and Transition: Amish Mennonites and Old Order Amish 1800-1900. Studies in Anabaptist and Mennonite History, Vol. 31. Scottdale: Herald.

Yoder, Paton and Steven R. Estes. 1999. Proceedings of the Amish Ministers' Meetings: 1862-1878. Goshen: Mennonite Historical Society. 